\title{
FALVAINK SORSA AZ EZREDFORDULÓN: A KÖZÉP-TISZAVIDÉKI TAPASZTALATOK
}

\author{
(Rural Settlements' Fate at the Turn of the Millennium: \\ Experiences of Mid Tisza Region)
}

\section{KISS EDIT ÉVA}

Kulcsszavak:

Közép-Tiszavidék, rurális fejlödés, életkörülmények, rendszerváltozás

A tanulmány a kevésbé fejlett Közép-Tiszavidék négy községében (Sarud, Tiszakeszi, Tiszaszentimre, Újszentmargita) 1998-ban végzett kérdöives felmérés tükrében mutatja be a rendszerváltozás után a falusi életkörülményekben (infrastruktúrális ellátottság, lakásviszonyok, lakások felszereltsége, jövedelmi helyzet, vásárlási szokások stb.) bekövetkezett változásokat: hogyan reagáltak azokra a háztartások és az egyének, s milyen stratégiákat alkalmaztak a fennmaradásuk érdekében.

\section{Bevezetés}

A XX. század végéhez közeledve falusi településeinkben is mélyreható változások mentek végbe, ugyanis 1989 után az élet minden területét átfogó radikális társadalmi, gazdasági reformok a falvakat sem hagyták érintetlenuil. Az ezred- és századforduló táján tehát falvaink ismét - csakúgy mint 1945-öt követỏen - óriási átalakuláson mentek keresztül, amelyek az utóbbihoz viszonyítva gyorsabban zajlottak le, habár bizonyos folyamatok még napjainkban is tartanak. A II. világháború után bekövetkezett változások fontosabb sajátosságait és a falvak jövőbeni fejlődésének lehetséges útjait Enyedi György foglalta össze „Falvaink sorsa" címủ 1980-ban megjelent könyvében. Ez a tanulmány sem terjedelmében, sem célkitüzéseiben nem vállalkozik (s nem is vállalkozhat) hasonló mértékú helyzetértékelésre, a magyar falvakban az elmúlt évtizedben lezajlott változások teljes áttekintésére. Sokkal inkább arra helyezi a hangsúlyt, hogy a változások egyetlen szegmensének, nevezetesen a falusi életkörülmények alakulásának aspektusából mutassa be falvaink sorsát az ezredfordulón néhány kỏzép-tíszavidéki községben végzett kérdöíves felmérés tapasztalatainak tükrében.

A téma választását alapvetően az indokolta, hogy a rendszerváltozás óta a falusi lakosság életkörülményeiben számottevỏ javulásnak és nagyfokú differenciálódásnak lehetünk a szemtanúi. Ez számos tényezövel magyarázható (pl. földrajzi fekvés, telepuilés mérete, népesség összetétele) és szorosan összefügg a poszt-szocialista falusi átalakulással, ami nagyon eltérő ütemben halad. Így az egyes községek a változás, a fejlődés más-más fázisában vannak. Ebból következően falvaink sorsa is különbözőképpen alakul a XX. század végén, ami 
viszont meghatározó jelentőségü jövőbeni lehetőségeik, perspektíváik szempontjából is. Kétségtelen, hogy azok fejlődtek és fejlődnek a legeröteljesebben, amelyek a leggyorsabban tudtak reagálni az új kihívásokra, a megváltozott politikai, gazdasági és társadalmi körülményekre, és amelyeknek ráadásul a földrajzi fekvése is kedvező. Ez tehát részben a lokális, ún. belsö, településen belüli adottságokra, erőforrásokra vezethető vissza, bár azokat a településre kívülről ható (politikai, társadalmi, gazdasági) tényezők is befolyásolták. Ám mostanra az is nyilvánvalóvá vált, hogy egyáltalán nem mindegy, hogy az adott község hol, az ország melyik részében helyezkedik el. Általános tapasztalat, hogy a föbb közlekedési tengelyek mentén és/vagy a nagyobb városok közelében levők dinamikusabban fejlödnek, mint a központoktól távol fekvő, rossz közlekedési adottságokkal rendelkező, periférikus, határ menti települések (Kiss 1989; Kovács 1991).

\section{1. ÁBRA}

A vizsgált közép-tiszavidéki falvak

(The Examined Settlements of Mid-Tisza Region)

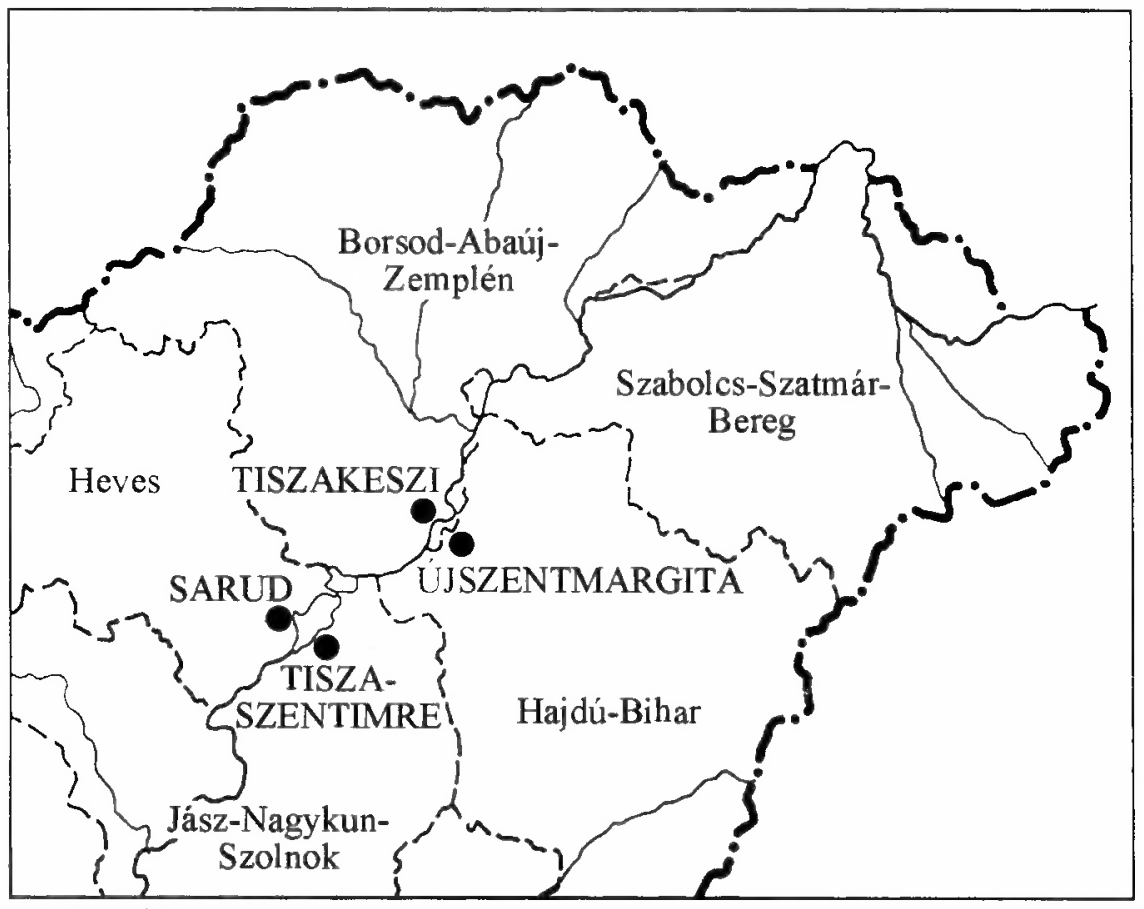

Forrás: Saját szerkesztés.

A hátrányos helyzetủ, megyehatár menti települések még mindig népes csoportjába sorolhatók azok a közép-tiszavidéki falvak (Sarud, Tiszakeszi, Tíszaszentimre, Újszentmargita) is, amelyek a részletes vizsgálódások színhelyéül szolgáltak (1. ábra). S tulajdonképpen e tanulmány keretei között a kutatás azon 
fontosabb eredményeit foglaljuk össze, amelyek azt mutatják be, hogy az adott településre kívülröl (ún. szupralokális faktorok, a politikai, gazdasági, kulturális tényezök) és a belülröl ható (ún. lokális, politikai, gazdasági, kulturális) faktorok kölcsönhatását hogyan élték meg a település aktorai (pl. háztartások, egyének), és milyen válaszokat adtak azokra, amelyek lényegében az ún. fennmaradási vagy túlélési stratégiának a megnyilvánulásai (Oksa 1997; Tykkyläinen 1997; Varis 1997). Azaz, hogyan változtak a falusi életkörülmények 1989 után, amelyeket elsösorban a lakáskörülmények és a lakókörnyezet milyensége szemszögébỏl közelítünk meg, hogyan reagáltak azokra a háztartások, továbbá, hogy milyen stratégiákat alkalmaztak a fennmaradásuk érdekében. Az itteni változások és az azokra adott válaszok feltehetően sok rokon vonást mutatnak az ország más falusi településeiben megfigyelhetőkkel, ezért a közép-tiszavidéki példák mintegy azok tükreként is szolgálnak. Valójában ezzel magyarázható a kiválasztásuk is, valamint azzal, hogy mivel ezek elmaradott, hátrányos helyzetü falvak, ezért feltételezhetö, hogy a jobb helyzetben levő falusi településekben az itt tapasztaltaknál kedvezőbb változások regisztrálhatók. $\mathrm{S}$ ez azt is jelenti, hogy jelenleg a településállományunk 93\%-át alkotó falvak zömében, valószínüleg még a reprezentatív településekénél is jobbak az életkörülmények. Legalábbis általánosságban véve, mert a különbségek fokozódása miatt, ami szintén velejárója volt a pozítiv tendenciáknak, az egyes háztartások, családok, illetve az egyének életszínvonala, életkörülményei ténylegesen igen eltérően alakultak. Ez sok tényező (pl. népesség száma, iskolázottsága, foglalkozása) függvénye, de a település nagysága, lélekszáma az egyik legfontosabb közülük. Hiszen a lakosság száma döntő jelentőségü lehet bizonyos intézmények, szolgáltatások megtelepedése, s helyben való rendelkezésre állása szempontjából. Rendszerint minél nagyobb, népesebb a település, annál jobb az intézményekkel, szolgáltatásokkal való ellátottsága. Ezen összefüggésre, melynek a gyökerei a XVIII. századra vezethetök vissza, már többek között Beluszky is felhívta a figyelmet (Beluszky 1999).

A négy település kiválasztásakor is meghatározó elem volt az, hogy a falvak melyik nagyságkategóriájához tartoznak. Ez azon megfontolásból fakadt, hogy ezáltal is minél inkább azon községek lakosainak életkörülmény-változásait fedjük fel, amelyekben a falusi népesség tetemesebb hányada él. (Még ma is az ország népességének 37\%-a él falvakban.) Ezen törekvéssel összhangban a középfalvakat, amelyek a falvak 16\%-át és a falusi népesség közel 38\%-át mondhatják a magukénak, Tiszakeszi és Tiszaszentimre képviselte. Az elöbbinek 2709, az utóbbinak 2637 lakosa volt 1998-ban. Sarud 1290 fös és Újszentmargita 1585 fös lakosságszámával a kisfalvak táborához tartozik, amelyet a falvak közel 23\%-a és a falusi lakosok durván $26 \%$-a alkot.

A kutatás célkitüzései miatt és részben, mert a „legfrissebb" statisztikai adatok csak 1990-böl álltak rendelkezésre, szükségesnek bizonyult az alaposabb helyszini 
vizsgálódás. Ez egyfelöl a lakosság körében 1998-ban végzett kérdöíves felmérést, másfelöl a helyi önkormányzati vezetőkkel és néhány képviselő testületi taggal (iskola igazgató, körzeti orvos, vállalkozó) készített interjúkat foglalta magában. A kérdőívekre, amelyek elsősorban a lakáskörülményekre és a települési környezetre vonatkoztak, Sarudon a háztartások 7,6\%-a, Tiszakeszin 4,6\%-a, Tiszaszentimrén 5,8\%-a, Újszentmargitán pedig 8,2\%-a válaszolt, miáltal Sarudon a népesség 11,3\%-áról, Tiszakeszin 6,4\%-áról, Tiszaszentimrén 11,3\%-áról, Újszentmargitán 12,3\%-áról nyertünk információt, amelyek mindenképp jelzésértéküek. A felmérés adatait az országos értékekkel összevetve még pontosabban értékelhetök az elmúlt évtizedbeli falusi életkörülmény-változások.

\section{A falusi életkörülmények 1989 után}

Az életkörülmények és az életmód sok elemből tevődik össze és számos tényező által meghatározottak (Bánlaky 1993; Weixlbaumer 1993). Ezek egyike az intézményi ellátottság, amely - tágabb értelemben - befolyásolja a lakosság életkörülményeit és szoros összefüggést mutat a település nagyságával. Mivel a kisebb településeken (falvakban) általában kevesebb intézmény található, ezért jóval szerényebb mértékü az ott élök alapfokú ellátottsága, mint a népesebb falvakban. Számukra a megoldást a jó közlekedési kapcsolatok biztosítása jelenti, amelyek fejlesztése elsőrendü feladat azért, hogy lakosaik rövid időn belül hozzáférhessenek a magasabb szintủ szolgáltatásokhoz. Ez különösen azon települések szemszögéböl rendkívül fontos, amelyek vasúton nem közelíthetök meg. Sarud és Tiszakeszi sem rendelkezik vasúttal, ami nemcsak a múltban, de napjainkban is hátrányosan hat, és ezt a megkérdezettek is hangsúlyozták. Tiszakeszit még az átmenő forgalom hiánya is sújtja. Mindezeken túlmenően periférikus helyzetükből adódóan a közúti közlekedés fejlettsége, milyensége (pl. a járatsürüség) is elmarad a kivánatostól.

Az alapfokú intézményi ellátottság, legalábbis az ilyen típusú intézmények (pl. óvoda, általános iskola, könyvtár, házi orvosi rendelö) meglétét tekintve kielégitő a vizsgált falvakban. Az önkormányzatok pénzügyi nehézségeik miatt azonban alapvetően a fenntartásukra és a kisebb rekonstrukciók, felújitások elvégzésére koncentráltak az elmúlt évtizedben. S csak nagyon kevés új beruházás valósult meg a rendszerváltozás óta. Ezek közé sorolható például az, hogy a közelmúltban Újszentmargitán gyógyszertárat építettek, Sarudon pedig egy 400 féröhelyes kempinget adtak át a falusi turizmus fejlődésének előmozdítása érdekében. A leglátványosabb változás a kereskedelem és a szolgáltatás terén következett be a vállalkozói szféra aktív közremüködésének köszönhetöen. 1989 után nagyon sokan különbözö megfontolásból a kereskedelemben vállalkoztak, s többen boltot nyitottak. Belejátszott ebbe a gyors meggazdagodás reményének csábító ereje, valamint a kicsi tỏkebefektetési igény is. A korábbi néhány bolt helyett ma már 
mindegyik faluban 30-nál is több üzlet müködik, kivéve Újszentmargitát, ahol 22. Általuk a falusi lakosság kereskedelmi ellátása sokat fejlödött, a mennyiségi gyarapodás a választék bővülésével és a boltok szakjelleg szerinti megoszlásának javulásával is együtt járt.

$\mathrm{Az}$ életkörülmények alakulását nagymértékben befolyásolja a "vonalas” infrastrukturális ellátottság milyensége is, ami a változások másik fö szinterét képezte. A falvak szinte mindegyikében óriási elörelépés történt a gáz-, a csatornaés a telefonhálózat kiépítésében, amit a következő országos községi adatok is bizonyítanak. 1990 és 1998 között az ezer lakosra jutó vezetékes gázt fogyasztó háztartások száma 37-röl 185-re szökkent fel, míg a közüzemi vízhálózatba bekapcsolt lakások aránya 71\%-ról 84\%-ra, a közüzemi csatornahálózatba bekötötteké durván 4\%-ról 12\%-ra növekedett. A falvak telefon-ellátottsága szintén gyors ütemben fejlődött és 1998-ban már 256 fövonal jutott ezer falusi lakosra szemben a 335-ös országos átlaggal. Ezen pozitiv eredmények eléréséhez erőteljesen hozzájárult a falusi lakosság is, mivel a költségek egy részét saját forrásaikból kellett fedezni. De nagyon sok múlott azon is, hogy milyen volt a helyi vezetés felkészültsége, „rátermettsége”, kapcsolatrendszere, és hogy mennyire gyorsan tudott reagálni az új kihívásokra. A humán tényező minősége, a lokális társadalom milyensége egyre fontosabb elem, $\mathrm{s}$ a települések fejlödésében játszott szerepe mindinkább felértékelödik (Mészáros 1988; Kiss 1992).

A négy településen a vezetékes vízellátásba bekapcsolt lakások aránya volt a legmagasabb (71-98\%), a vezetékes gázzal és telefonnal felszerelt lakások aránya sokkal nagyobb szóródást mutatott, mivel 30-75\% között változtak az értékek. Ám a legrosszabb helyzet mégis a csatornába való bekötöttség esetében figyelhető meg Tiszakeszi (18\%) és Sarud (15\%) kivételével, ahol a mértéke az országos községi átlagot $(12 \%)$ is meghaladta. A XX. század végén tehát úgy tủnik, hogy ez az egyik legmarkánsabb differenciáló elem a falusi életkörülményekben. Egyébként összességében véve is Tiszakeszi infrastrukturális ellátottsága a legkedvezöbb, ami valószínüleg nemcsak annak tudható be, hogy ez a legnépesebb a négy község közül, hanem annak is, hogy több ipartelep is müködött itt a szocializmus évtizedeiben, azaz e település volt a „legurbánusabb” a vizsgált falvak közül. A lokális tapasztalatok alapján az is nyilvánvalóvá vált, hogy a falvak vonalas infrastrukturális ellátottsága ma már nincs szoros összefüggésben a település méretével, hiszen mostanra már számottevően mérséklődtek a falvak ilyen jellegü ellátottságában korábban tapasztalt különbségek. Ugyanakkor Sarud viszonylag kiemelkedően magas csatornázottságát feltehetően a nagyobb mérvü turista forgalom magyarázza, ugyanis Tisza-tó menti fekvése miatt igen kedvelt üdülőhely (1. táblázat).

A települési környezetben zajló kedvezö változásokkal a megkérdezettek zöme elégedett volt. A legtöbb kritikát a kereskedelmi ellátás és a kulturális 
Kiss Edit Éva : Falvaink sorsa az ezredfordulón : A közép-tiszavidéki tapasztalatok

Tér és Társadalom 15. évf. 2001/1. 153-169. p.

158 Gyors ténykép

TÉT XV. évf. 2001

szolgáltatások kapták (pl. kicsi az áruválaszték, kevés a szaküzlet, nincsenek kulturális rendezvények), amelyek alapján arra lehet következtetni, hogy ma már nemcsak az intézmények jelenléte, mennyisége a fontos, hanem mindenekelőtt szolgáltatásaik szinvonala, áruik minősége és ára.

\section{TÁBLÁZAT}

A lakások felszereltsége és komfortfokozata a közép-tiszavidéki falvakban, 1990-1998

(Utilities and Comforts of Dwellings in the Settlements of Mid Tisza Region)

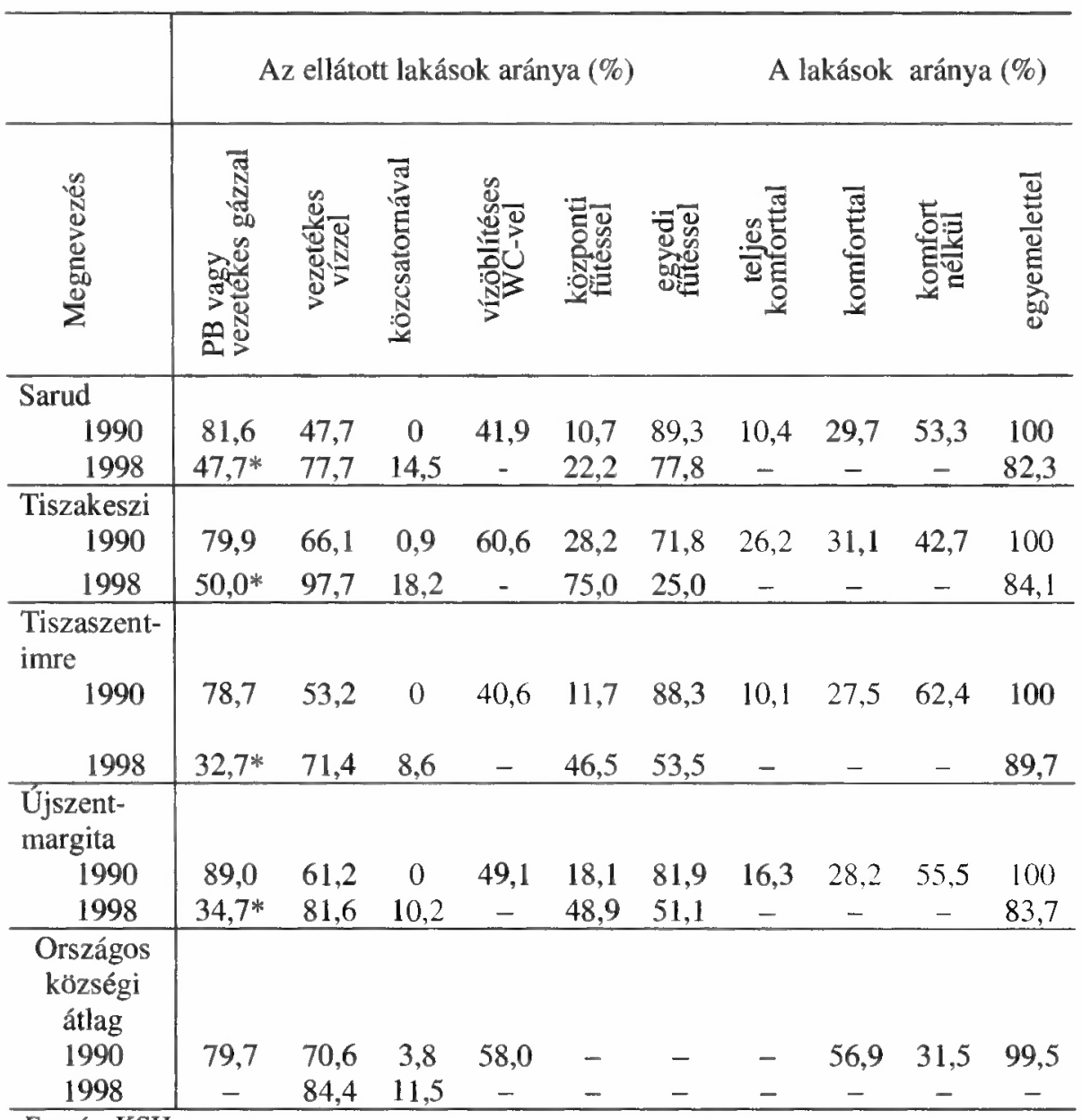

Forrás: KSH.

A kedvezötlen vélemények és panaszok ellenére a válaszolók tekintélyes hányada elsősorban mégsem az infrastrukturális ellátáshoz kapcsolódóan fogalmazta meg azokat a feladatokat és gondokat, amelyeket a legsürgösebben meg kellene oldani az adott településen. Ezek legtöbbször a munkanélküliséggel, az elszegényedéssel, a 
közbiztonság romlásával függtek össze, amelyek csak látszólag állnak távol egymástól, lényegében egy tőről fakadnak, s egymással szoros kölcsönhatásban vannak.

Szúkebb értelemben a lakosság életkörülményeit leginkább a lakóház, illetve a lakás milyensége, felszereltsége, komfortfokozata határozza meg. Éppen ezért egyáltalán nem mindegy, hogy mi jellemzi ezen szempontból a falvak lakóit. A lokális vizsgálatok azt jelzik, hogy ebbỏl az aspektusból már jóval jelentősebb szerepe van a lakóház településen belüli elhelyezkedésének. Másképpen fogalmazva a lakóházak minőségére, felszereltségére már a falun belüli elhelyezkedésükből is következtetni lehet bizonyos fokig. Az utóbbi években a falusi élettér is eróteljes differenciálódáson megy keresztül, amit alapvetően az emberi szükségletek szabad érvényesülése formál, és aminek csak az adott ember anyagi erőforrásai és egyéb tényezők szabnak korlátokat szemben a szocialista időszakkal, amikor mindent felülről szabályoztak, s az emberek szabad döntései (pl. lakóhelyválasztás) erỏsen korlátozva voltak.

Az 1990-es évtized, de különösen a rendszerváltozást követỏ évek nem igazán kedveztek a lakásépítésnek, s ez tükröződött az épített lakások számában is. 1990 és 1998 között 17 146-ról 7884-re zuhant a falvakban épített lakóházak száma, ami az országos érték durván egyharmadát tette ki. Ez a nagyarányú csökkenés pl. az építőanyagárak drasztikus emelkedésével, a magas hitelkamatokkal és a romló hitelfeltételekkel, továbbá a növekvő megélhetési költségekkel stb. magyarázható. Ráadásul sok embernek a munkahelye is veszélybe került vagy el is vesztette az állását, így nem is igen vállalkozhatott lakóház építésére. A közép-tiszavidéki falvakban - részben az elöbb felsorolt tényezők miatt, valamint a periférikus fekvés és a lakosság szerényebb jövedelmi viszonyai miatt - szintén kevés lakás épủlt az elmúlt években, ami a lakásállomány elöregedésének a fokozódásához vezetett. Sarudon a megkérdezettek lakóházainak 23\%-a, Tiszakeszin 13\%-a, Tiszaszentimrén 16\%-a, Újszentmargitán 14\%-a épült a rendszerváltozást követően, ám a többség lakóháza húsz éve vagy annál régebben épült. A tulajdonosok legnagyobb hányada maga építette lakóházát (Sarudon 43\%-uk, Tiszakeszin 66\%uk, Tiszaszentimrén 55\%-uk, Újszentmargitán 53\%-uk), majd azok csoportja kỏvetkezett, akik vásárlás révén jutottak hozzá (2. táblázat).

A lakóházak minősége, komfortfokozata és a falu nagysága között nem mutatható ki szoros összefüggés. Ellenben a lakóházak kora és ellátottsága már jóval erőteljesebb összefonódást mutat. Rendszerint az újonnan épített lakások, amelyek legalább háromszobásak és túlnyomó részben egyemeletesek, vannak jobban felszerelve és közmüvekkel szinte teljesen ellátva. Ezzel szemben a régi lakóházak közmüvesítésében jelentős differenciák tapasztalhatók, fỏként a csatornába való bekötöttségük igen alacsony, s nagyon gyakran fürdőszobával sem rendelkeznek. A közép-tiszavidéki lakóházak zöme földszintes és jobbára kétszobás, habár az utóbbi 
Kiss Edit Éva : Falvaink sorsa az ezredfordulón : A közép-tiszavidéki tapasztalatok

Tér és Társadalom 15. évf. 2001/1. 153-169. p.

esztendökben gyors ütemben gyarapodnak a háromszobásak is. Arányuk Sarudon elérte a 46\%-ot, Tiszakeszin a 70\%-ot, Tiszeszentimrén az 50\%-ot, Újszentmargitán a 47\%-ot. A magasabb szobaszámmal egyidejủleg jobb lett a lakások közmüvekkel való ellátottsága is, dacára annak, hogy a csatornával való ellátottságuk még mindig a legcsekélyebb. Szélesedett a központi fütéssel és fürdöszobával rendelkezö lakóházak köre is, s ma már az utóbbi nem olyan markáns differenciáló elem mint a szocializmus évtizedeiben volt (Enyedi 1980).

\section{TÁBLÁZAT}

A lakások fontosabb jellemzöi a közép-tiszavidéki falvakban, 1990-1998

(Main Characteristics of Dwellings in the Settlements of Mid Tisza Region)

\begin{tabular}{|c|c|c|c|c|c|c|c|c|c|}
\hline \multirow{2}{*}{ 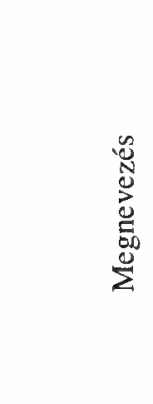 } & \multirow{2}{*}{ 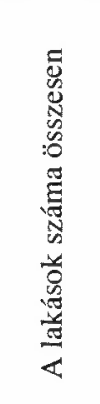 } & \multicolumn{3}{|c|}{ Ebböl (\%) } & \multicolumn{3}{|c|}{$\begin{array}{l}\text { A lakások } \\
\text { szobaszáma } \\
\text { szerint } \\
(\%) \\
\end{array}$} & \multicolumn{2}{|c|}{$\begin{array}{l}\text { A lakások az } \\
\text { építés éve } \\
\text { szerint (\%) }\end{array}$} \\
\hline & & 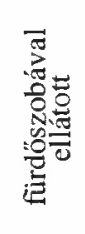 & 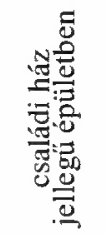 & 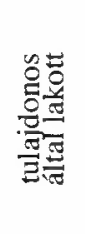 & - & N & $\begin{array}{l}0 \\
0 \\
0 \\
0 \\
m \\
m\end{array}$ & 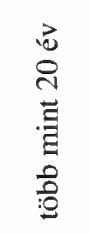 & 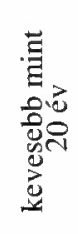 \\
\hline $\begin{array}{l}\text { Sarud } \\
1990 \\
1998 \\
\end{array}$ & $\begin{array}{c}576 \\
44 \\
\end{array}$ & $\begin{array}{l}46,7 \\
31,8 \\
\end{array}$ & $\begin{array}{c}96,4 \\
100,0\end{array}$ & $\begin{array}{l}86,7 \\
89,9\end{array}$ & $\begin{array}{c}11,5 \\
3,0 \\
\end{array}$ & $\begin{array}{l}54,0 \\
51,5\end{array}$ & $\begin{array}{l}34,5 \\
45,5\end{array}$ & $\begin{array}{l}91,1 \\
52,8\end{array}$ & $\begin{array}{r}8,9 \\
47,2\end{array}$ \\
\hline $\begin{array}{c}\text { Tiszakeszi } \\
1990 \\
1998 \\
\end{array}$ & $\begin{array}{c}997 \\
44 \\
\end{array}$ & $\begin{array}{l}64,5 \\
59,1 \\
\end{array}$ & $\begin{array}{c}95,9 \\
100,0 \\
\end{array}$ & $\begin{array}{l}29,3 \\
90,9 \\
\end{array}$ & $\begin{array}{c}13,9 \\
4,5 \\
\end{array}$ & $\begin{array}{l}42,5 \\
25,0\end{array}$ & $\begin{array}{l}43,6 \\
70,5 \\
\end{array}$ & & $\begin{array}{l}48,5 \\
54,6\end{array}$ \\
\hline $\begin{array}{r}\text { Tisza- } \\
\text { szentimre } \\
1990 \\
1998 \\
\end{array}$ & $\begin{array}{c}1005 \\
58 \\
\end{array}$ & $\begin{array}{l}50,0 \\
34,1 \\
\end{array}$ & $\begin{array}{c}92,9 \\
100,0\end{array}$ & $\begin{array}{l}88,0 \\
89,7 \\
\end{array}$ & $\begin{array}{c}16,2 \\
5,2 \\
\end{array}$ & $\begin{array}{l}55,4 \\
44,8 \\
\end{array}$ & $\begin{array}{l}28,4 \\
50,0 \\
\end{array}$ & $\begin{array}{l}70,0 \\
69,0 \\
\end{array}$ & $\begin{array}{l}30,0 \\
31,0 \\
\end{array}$ \\
\hline $\begin{array}{c}\text { Újszent- } \\
\text { margita } \\
1990 \\
1998 \\
\end{array}$ & $\begin{array}{c}609 \\
49 \\
\end{array}$ & $\begin{array}{l}61,1 \\
30,6 \\
\end{array}$ & $\begin{array}{c}90,1 \\
100,0\end{array}$ & $\begin{array}{l}87,8 \\
98,2 \\
\end{array}$ & $\begin{array}{l}22,0 \\
12,2 \\
\end{array}$ & $\begin{array}{l}46,5 \\
40,8 \\
\end{array}$ & $\begin{array}{l}31,5 \\
47,0 \\
\end{array}$ & $\begin{array}{l}63,8 \\
38,7 \\
\end{array}$ & $\begin{array}{l}36,2 \\
61,3 \\
\end{array}$ \\
\hline $\begin{array}{l}\text { Országos } \\
\text { községi } \\
\text { átlag } \\
(1990) \\
\end{array}$ & $1,38 \mathrm{M}$ & 70,0 & 93,8 & 91,2 & 14,2 & 41,4 & 44,4 & - & - \\
\hline $\begin{array}{l}\text { Országos } \\
\text { átlag } \\
(1990)\end{array}$ & $68 \mathrm{M}$ & 82,6 & 59,8 & 73,9 & 15,9 & 43,6 & 40,5 & - & \\
\hline
\end{tabular}

- Nincs adat.

Forrás: Az 1990. évi népszámlálás megyei kötetei és összefoglaló kötete; kérdőives felmérés 1998. 
Elsődlegesen a kedvező változásokkal indokolható, hogy a választ adóknak csak a töredéke nem volt elégedett lakáskörülményeivel. Elképzelhető, hogy a kisebb igényszintek is belejátszottak ebbe, ami a lakosság összetételéböl, alacsonyabb iskolázottsági fokából és a roma lakosság tetemesebb előfordulásából fakadhat. Az 1990-es népszámláláskor az általános iskolát nem végzettek aránya (ami 2,8 és $3,4 \%$ között volt) mind a négy településen jóval meghaladta az országos $(2,0 \%)$ és az országos községi átlagot $(2,6 \%)$, ezzel szemben a diplomásoké (akiknek az aránya 2,4 és 3,0\% között mozgott a vizsgált falvakban) elmaradt azoktól (3,1\%, illetve 7,6\%). A roma népesség arányát Sarudon 40\%-ra, Tiszakeszin 30\%-ra, Ứjszentmargitán $10 \%$-ra becsülték, ami sokkal magasabb az országos értéknél (kb. $5 \%$ ). Az elégedetlenkedők a legsürübben a következő okokat említették: a lakóház kicsi, sötét, vizes, penészes, nem jó a szigetelése, fel kellene újítani, ki kellene bővíteni. A megoldáshoz szükséges pénz előteremtése sok család számára igen nagy teher a fenntartási költségek, illetve az ,élet általános drágulása" miatt. Éppen ezért érthető, hogy a háztartások elsőként a túlélésre, a létfenntartásra összpontosítanak, s a lakásfelújítást vagy bővítést halasztják el inkább. A lakások tartós fogyasztási cikkekkel való felszereltségében szintén lényeges javulás következett be 1989 utản, melyeknek - egyes cikkektöl függően - 20-40\%-át vásárolták azóta. Különösen igaz ez a telefonra és a számítógépre, valamint a mosogatógépre (bár ez valószínüleg sok városi háztartásból is hiányzik), amelyekkel a legrosszabb volt a háztartások ellátottsága. Ellenben a háztartások tekintélyes része rendelkezett televízióval és hütőszekrénnyel. Az elöbbiek relatíve alacsony előfordulásáért feltehetően a falvak kedvezőtlen földrajzi fekvése is okolható, ami miatt az innovációk sokkal később jelennek meg, és jóval lassabban terjednek. Mivel a tartós fogyasztási cikkek közül sokat még az 1990-es évek első felében vásároltak, ezért nagy a valószínüsége annak, hogy az ezekre elköltött pénz nagy részét még a szocializmus időszakában takarították meg. Probléma akkor fog jelentkezni, amikor ezek a megtakarítások elfogynak, s ezért az elromlott eszközöket nem tudják majd kicserélni, hiszen az elmúlt évtized nem kedvezett a lakossági megtakarításoknak. Ebben az időszakban a háztartások túlnyomó hányada alapvetően a túlélésre, a megélhetés biztosítására rendezkedett be, $\mathrm{s}$ visszafogta ilyen irányú beruházásait. Az 1989-es év tehát mint egy éles határ, „választóvonal” jelentkezik a háztartások életében a tartós fogyasztási cikkekre való költés tekintetében (3. táblázat).

Sok helyütt és sokan ma is a tehetősség, a vagyonosság szimbólumának tekintik a személyautó birtoklását. Szembetünően jelezheti a jövedelmi viszonyokban és részben az életkörülményekben meglevő különbségeket. Az elmúlt évtizedben nemcsak a személyautók száma gyarpodott, hanem a személygépkocsi-állomány összetételében is markáns eltolódás következett be. Nőtt a tíz évnél idősebb gépkocsik aránya, s több lett a nyugati típusú gépkocsi is. Amíg 1990-ben átlagosan 
187 autó jutott ezer lakosra, addig 1998-ban már 220, de a vizsgált falvakban csak 91. A Közép-Tiszavidéken átlagosan a háztartások egyharmadának volt 1998-ban autója, Sarudon azonban a gépkocsik 71\%-ának, Tiszakeszin 62\%-ának, Tiszaszentimrén 85\%-ának, Újszentmargitán pedig 84\%-ának a kora már meghaladta a tíz esztendót. Részben ebböl is következik, hogy a többségüket a kelet-európai gyártmányok alkották. Mindössze néhány olyan háztartás akadt a megkérdezettek között, ahol két vagy esetleg több autót is magukénak mondhattak. Ez a nagyon szük kör lényegében a helyi vállalkozókból tevődött össze, akiknek a munkájukhoz nélkülözhetetlenek a jármüvek.

\section{TÁBLÁZAT}

A háztartások felszereltsége tartós fogyasztási cikkekkel a közép-tiszavidéki falvakban, 1998

(Households with Durable Goods of in the Settlements of Mid Tisza Region)

\begin{tabular}{|c|c|c|c|c|c|c|c|c|c|c|}
\hline \multirow[t]{2}{*}{ 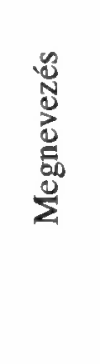 } & 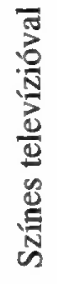 & $\begin{array}{l}\overline{7} \\
0 \\
0 \\
0\end{array}$ & 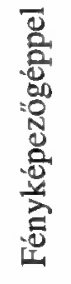 & 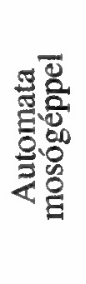 & 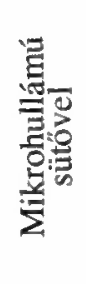 & 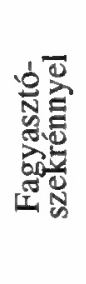 & 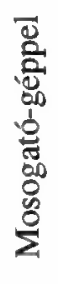 & 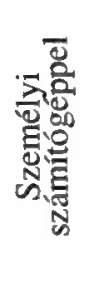 & 宽 & 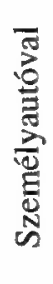 \\
\hline & \multicolumn{10}{|c|}{ ellátott lakások aránya (\%) } \\
\hline Sarud & 82 & 39 & 36 & 45 & 25 & 59 & 2 & 16 & 48 & 32 \\
\hline $\begin{array}{l}\text { Tisza- } \\
\text { keszi }\end{array}$ & 91 & 66 & 57 & 48 & 32 & 80 & 5 & 14 & 73 & 54 \\
\hline $\begin{array}{l}\text { Tisza- } \\
\text { szent- } \\
\text { imre }\end{array}$ & 81 & 34 & 37 & 36 & 12 & 60 , & 0 & 3 & 68 & 33 \\
\hline $\begin{array}{l}\text { Új- } \\
\text { szent- } \\
\text { mar- } \\
\text { gita }\end{array}$ & 84 & 57 & 37 & 29 & 14 & 53 & 2 & 8 & 45 & 35 \\
\hline
\end{tabular}

Forrás: Kérdöives felmérés 1998.

Az összességében véve pozitív változások ellenére Sarudon a megkérdezettek 64\%-a, Tiszakeszin 66\%-a, Tiszaszentimrén 27\%-a, Újszentmargitán 63\%-a vélekedett úgy, hogy lakóhelye hátrányt jelent valamilyen szempontból (pl. munkalehetőségek hiánya, periférikus földrajzi fekvés), de mégis csak nagyon kevesen foglalkoznak az elköltözés gondolatával, amibe az is belejátszik, hogy lakóházuk értékesítése komoly nehézségekbe ütközik, ezért hosszú távon az itt lakók mobilitása erösen korlátozott, vagy másképpen fogalmazva „,helyhezkötöttségük fokozódott” az elmúlt esztendőkben. 


\section{A háztartások reakciói a változásokra}

$\mathrm{Az}$ életkörülmények alakulását egyebek mellett a jövedelmi viszonyok és a megtakarítások is befolyásolják. Az utóbbi években az árak hatalmas léptékben emelkedtek, így a háztartások túlnyomó része, a közép-tiszavidékiek 77-96\%-a már egyáltalán nem tud pénzt megtakarítani a hó végén. Azok pedig, akik nem tudják beosztani a rendelkezésre álló összeget a leggyakrabban (34-49\%) kölcsönkéréssel fedezik a hiányt. Mások viszont korábbi, 1989 elötti megtakarításaikat élik fel, habár az 1990-es évek végére ezek a tartalékok már csaknem teljesen kimerültek. Egyébként a felmérésbe bevontak véleménye megegyezett abban, hogy az 1989 elötti anyagi helyzet, mint ,indulási állapot” nagymértékben kihatott a család 1989 utáni pénzügyi helyzetére, mintegy predeterminálta azt. Ebből következően, akik a rendszerváltozást megelőzően is jobb körülmények között éltek, rendelkeztek megtakarítással, azok sokkal „könnyebben” tudták átvészelni a rendszerváltozás megpróbáltatásait (pl. munkahely elvesztése, növekvő árak). Sőt még a hitelekhez is gyorsabban, egyszerübben hozzájuthattak, miáltal magánvállalkozásokat is viszonylag zökkenőmentesebben tudtak létrehozni.

A vizsgált falvakban a magas kamatok és az alacsony jövedelmek miatt a háztartások 20-30\%-a tudott csak valamilyen hitelt felvenni 1989 után, hogy pénzủgyi nehézségeit megoldja. Ezt bizonyítja az is, hogy a legtöbb esetben olyan hitelt (pl. személyi hitel) vettek fel, amelyet különböző célra lehetett felhasználni. Sarudon a háztartások 30\%-a, Tiszakeszin 16\%-â, Tiszaszentimrén 33\%-a, Újszentmargitán 6\%-a vett fel személyi hitelt 1989 után, ami a túlélési stratégia egyik releváns elemének tekinthetö. Ugyanakkor a másik gyakori hitelféleséget, az építési hitelt, amelyek törlesztôrészletei szintén sok családi kasszát terhelnek, föleg 1989 elött vették fel. Az egyéb hitelfajták közül még az áruvásárlási érdemel említést. Az, hogy viszonylag kevesen folyamodtak ilyen hitelhez az elmúlt évtizedben szintén arra enged következtetni, hogy a lakosság korlátozta ilyen irányú kiadásait, amit az is megerősít, hogy az áruvásárlási hiteltörlesztök nagyobb hányada (pl. Sarudon 60\%-a, Tiszaszentimrén 67\%-a) is még 1989 előtt vásárolta részletre tartós fogyasztási cikkeit. Az is bizonyságot nyert a kutatás során, hogy a kölcsönt fel nem vettek táborának van egy olyan - talán egyre terebélyesedő csoportja is, akik végképp kiszorulnak a potenciális hitelt igénylök köréböl. Ök azok, akik a lokális társadalom legszegényebb, legelesettebb rétegeit alkotják.

A megélhetési nehézségekből következik, hogy többnyire kevés azon háztartások aránya (Sarudon 9\%-a, Tiszakeszin 25\%-a, Tiszaszentimrén 3\%-a, Újszentmargitán $10 \%$-a), ahol valamire gyüjtenek. Feltételezhetö, hogy ebbe az a szemléletbeli változás is belejátszik, amely a bizonytalanság, kiszámíthatatlanság miatt inkább a „pillanatnyi helyzetnek való élést” részesíti előnybe. Ezt látszik alátámasztani az is, hogy azok, akik mégis megpróbálnak takarékoskodni, többnyire rövid távon, a közeli jövőben megvalósítható célok érdekében teszik azt. A leggyakoribbak a 
lakosság megélhetéséhez, a fennmaradáshoz és a lakáskörülmények javításához kapcsolódtak. Pélđául azért spórolnak, hogy nyugodtan, biztonságosan meg tudjanak élni, hogy mindig ki tudják fizetni a különbözö számlákat és meg tudják venni a tüzelöt télire, hogy cipöt tudjanak vásárolni a gyermekeknek, hogy felújítsák vagy bővítsék a lakást. Említhetők viszont olyan indítékok is, hogy a gyermekek továbbtanulására kuporgatnak, vagy nyaralásra, esetleg egy új autóra és/vagy számitógépre. Az idősek közül jónéhányan saját temetésükre rakják félre a pénzt, tudván azt, hogy gyermekeik anyagi helyzete nem teszi lehetővé a temetési költségek részbeni vagy teljes fedezését.

A szocializmusban a családok megélhetését jelentősen segitette a ház körüli növénytermesztés és állattartás, valamint a felesleg eladásából származó bevétel. Ezek szinte elengedhetetlenek voltak a pénzmegtakarításhoz, a tőkefelhalmozáshoz, amiből azután finanszírozni tuđták a lakáskörülményeik javításához és életszínvonaluk emeléséhez szükséges kiadásokat (Tamasi 1993). Ebben a térségben azonban a mezőgazđasági termelés szempontjåból kedvezötlen (pl. talaj) ađottságok és a piacok távolsága miatt csak nagyon kevés lehetóség nyilt többletjövedelem szerzésére a mezőgazdasági termékfelesleg eladásából, így az életkörülmények fejlesztéséhez sem járult hozzá számottevő mértékben. $\mathrm{S}$ ez bizonyos fokig a térség mai napig is meglevő elmaradottságát, hátrányát is magyarázza. Az utóbbi évek radikális változásai (pl. emelkedő árak, dráguló szállítási költségek, kereslet csökkenés) a háztartások tekintélyes részét arra ösztönözte, hogy még azt a kevés felesleget is jobbára maguk éljék fel, illetve, hogy önellátásukra nagyobb hangsúlyt helyezzenek. Ennek tulajdonítható, hogy Sarudon a háztartások $76 \%$-a foglalkozik növénytermesztéssel és $42 \%$-a állattartással, főként sertés-, baromfitartással. Ugyanezen tevékenységek értékei Tiszakeszin $73 \%$ és $70 \%$, Tiszaszentimrén $76 \%$ és $66 \%$, Újszentmargitán pedig $88 \%$ és $69 \%$. Mindkét mezőgazdasági jellegủ munkát elsősorban a ház körül, alapvetően a saját szükséglet kielégitése érdekében végzik. Az önellátásra való berendezkedés erősödése szintén fontos eleme a túlélési stratégiának.

$\mathrm{Az}$ elmúlt évtizedben a vásárlási szokások is gyökeresen átalakultak, amit többek között - a folytonosan emelkedő árak és az azokkal lépést nem tartó alacsony keresetek, $\mathrm{s}$ magán a kereskedelmi ellátáson belul végbement változások váltottak ki. A háztartások egyre nagyobb figyelmet fordítanak arra - s ezt a felmérések is tanusítják -, hogy hol, mi kerül kevesebbe, és hogy minél takarékosabban vásároljanak. A gyorsan romlandó és a „naponta” szükséges élelmiszereket (pl. tej- és tejtermékek, kenyér és péksuitemény) többnyire a helyi boltokban vásárolják. Ennél fogva a kisebb értékủ, napi bevásárlások jobbára a helyi boltokhoz kapcsolódnak, míg a nagyobb összegü, ritkább bevásárlások jelentős hányadánál már a más településeken levő boltok, diszkont üzletek jöhetnek inkább számításba, ha ott olcsóbbak az adott termékek. Ezeket föként azok keresik 
fel, akiknek autójuk van, s akkor nagy tételben vásárolnak, mert csak így kifizetődő. $\mathrm{Az}$, hogy az ár mennyire döntö tényező azt az is mutatja, hogy Sarudon a megkérdezettek 66\%-a, Tiszakeszin 61\%-a, Tiszaszentimrén 54\%-a, Újszentmargitán 53\%-a hajlandó más településekre, általában a közeli városokba elmenni azért, hogy ott vásároljon be.

Szintén a fennmaradási stratégia részeként értékelhető az a lakossági reakció, amely a ruházati cikkekre fordított összegek erőteljes redukálását vonta maga után. Teljesen érthető, hogyha a létfenntartás veszélybe kerül, akkor a háztartások az egyéb, pl. a ruházkodásra fordítandó kiadásokat csökkentik. Tekintélyes summát spórolhatnak meg azáltal, hogy ritkábban mennek ilyen üzletekbe, és hogy rendszerint az olcsóbb termékeket veszik. Ez utóbbinak tudható be, hogy sokan a piacokat és a használt ruha kereskedéseket részesítik előnyben, ami egyben azt is jelenti, hogy a minöség az másodlagos szempont. A döntö tényezö az ár még akkor is, ha az olcsóbb áru élettartama rövidebb, $\mathrm{s}$ ezért sürúbben kell azt vásárolni. Mivel ruházati cikkekre ritkábban van szükség, és a lokális üzletek kínálata eléggé szükös, ezért ezen árucikkek vásárlásakor elsődlegesen a nem helyi üzleteket veszik igénybe. De a háztartások úgy is megkísérlik megelözni a „felesleges “ pénzköltést, hogy ritkábban mennek boltokba, hogy nem vagy jóval kevesebbet vesznek bizonyos élelmiszerekből (pl. hús, felvágottak, tej, sajt, édesség) és élvezeti cikkekböl, valamint egyéb termékekböl (könyv, újság, háztartási gépek), ugyanazon termékcsoportból pedig az olcsóbbat választják. Ezeken túlmenően nem vásárolnak félkész- vagy kész konyhai termékeket, hanem amit lehet, azt maguk készítik el. A válaszokból kiderült, hogy Sarudon a háztartások 36\%-a, Tiszakeszin 25\%-a, Tiszzaszentimrén 37\%-a, Újszentmargitán 39\%-a egyáltalán nem járat vagy nem vásárol rendszeresen valamilyen újságot, ami talán nem csak a takarékosság jele.

Ugyancsak túlélési stratégiaként kezelhető az étkezési szokások megreformálása, amelynek okai mélyebben gyökereznek, mint a vásárlói magatartásnak a módosulása, de valószínüleg az is hozzájárult. E változásnak, amit valamelyest a kényszer szült, lényegében három gyakori megjelenési formája különíthető el, amelyek közül azonban egyik sem igazán vonzó, habár az utóbbi kettő nem annyira drasztikus mint az első, nevezetesen, hogy kevesebbszer és kevesebbet esznek. A másik két alternatíva inkább a táplálkozásstruktúra megváltozásához kapcsolódik. Vagy kevesebb húst, édességet, sajtot, tejet fogyasztanak és több zöldséget, kenyeret, tésztafélét, vagy alapvetöen azt eszik, amit a ház körül a kertben termelnek és azon állatok húsát fogyasztják, amilyeneket tartanak. Ez utóbbi lényegében a táplálkozás egyoldalúbbá válásához vezethet, aminek a tartóssága hosszú távon betegségek kialakulását is előmozdíthatja. Azt a válaszolók egy jelentős része maga is világosan látja, hogy egészségtelenebb lett a táplálkozása, de az objektív tényezők (pl. magas árak, szerény jövedelem) miatt úgy 
vélik, hogy jelenlegi anyagi helyzetük nem teszi lehetővé az egészségesebb táplálkozás megvalósítását.

A magánvállalkozások elterjedése kedvezően hatott a falvak szolgáltatásokkal való ellátottságára is. Ám a szolgáltatók körének bővülésével egyidejüleg csökkent az azokat igénybe vevők száma. Ugyanis a lakosság zöme a fennmaradás, a megélhetés biztosítása érdekében csak a legszükségesebbekre (pl. fodrász, cipész) költ, és azokra is ritkábban. Egyre gyakoribb, hogy az egyszerủ javításokat, szereléseket saját maguk végzik el, vagy a rokonok, barátok, ismerősök egymásnak végzett munka révén segítik egymást, azaz nem pénzzel, hanem munkával viszonozzák a szívességet. A falusi településeken a rokoni, baráti kapcsolatok számottevően enyhíthetik akár a rosszabbodó életkörülményeknek, akár a munkanélküliségnek az elviselését, sokkal jobban támaszkodhatnak egymásra, vagyis még mindig szorosabb az összetartó erő, mint a városokban (Benedek 1994).

\section{A változásokra adott egyéni reakciók}

Az elmúlt évtizedben az egyes emberek életét, sorsának alkulását sem hagyták érintetlenül az ország egészében és az élet minden területén zajló reformok. Természetesen a hatás mértéke térben és időben, valamint a különböző társadalmi csoportokhoz tartozóknál eltérően érvényesült. Ennek ellenére felfedhetők olyan tendenciák, jellegzetes vonások, amelyek általánosnak ítélhetők. Ezek egyike, ami egyúttal a leglényegesebb változás is, hogy 1989 után megnövekedett a munkaidö, illetve a munkával töltött idő hossza. Sarudon a válaszolók 31\%-a, Tiszakeszin 30\%-a, Tiszaszentimrén 24\%-a, Újszentmargitán pedig 33\%-a tapasztalta ezt. A bizonytalanság és részben a kis keresetek miatt sokan kénytelenek egyéb, pl. alkalmi munkát is vállalni, vagy a ház körül dolgozni, hogy a megélhetéshez szükséges jövedelmet elö tudják teremteni. A több vagy többféle munka vállalalására való törekvés, a „több lábon állás” vagy másképpen fogalmazva a gazdasági tevékenységek diverzifikálása nem csak magyarországi és nem csak a falusi háztartások fontos túlélési stratégiája.

Ugyanakkor az alvásra és különösen a pihenésre fordítható idő mennyisége jóval kevesebb lett. Ez, valamint a fokozódó munkahelyi elvárások, a növekvő felelősség, a félelem a munkahely elvesztésétől, az állandó alkalmazkodás az új kihívásokhoz, a kiszámíthatatlanság és az egyre gyakoribb, szinte állandósuló stressz együttesen eredményezik azt, hogy jelentősen romlott a lakosság egészségi állapota az 1990-es évtizedben. Sarudon a megkérdezettek 35\%-a, Tiszakeszin 34\%-a, Tiszaszentimrén $38 \%$-a, Újszentmargitán $41 \%$-a számolt be erröl, ami leggyakrabban az idegesség fokozódásában, az ingerültebb, feszültebb állapot nagyobb gyakoriságában, a dohányzás erősödésében, az alkohol- és a gyógyszerfogyasztás növekedésében nyilvánult meg. A legtöbb család havonta legalább egyszer felkeresi a patikát, de vannak olyanok is (Sarudon a felmérésbe bevontak 14\%-a, Tiszakeszin 7\%-a, 
Tiszaszentimrén 21\%-a, Újszentmargitán 8\%-a), akik hetente járnak oda, s többnyire ezer forint körül költenek ott. A lakosság romló egészségi állapota nem falusi jelenség, de falvainkban még az országos átlagnál is rosszabb az ott lakók egészségi állapota (Andorka 1996).

Az 1989 utáni új társadalmi rendszer a legradikálisabb változást azok életében okozta, akik munkanélkülivé vagy vállalkozóvá váltak. Az előbbiek a megnövekedett ,szabad idejükkel" nem tudnak mit kezdeni, de a feleslegesség, a kilátástalanság érzésével való megküzdés, ezeknek a feldolgozása, továbbá a kereset kiesés valahogyani pótlása is hatalmas terhet jelent. Kedvezötlen, hogy különböző okokra visszavezethetően - még ma is jóval magasabb ezekben a falvakban a munkanélküliségi ráta (Sarudon 20\%, Tiszakeszin 30\%, Tiszaszentimrén $38 \%$, Újszentmargita 18\%), mint az országos átlag (6\%). A legnagyobb gond az, hogy ennek a megoldására a helyi vezetők szerint hosszú távon sincs igazán kilátás. A munkanélküliek közül sokan különféle segélyekböl, tảmogatásokból élnek, amelyek előteremtése nagyon megterheli a helyi költségvetéseket.

A munkanélküliek között akadtak olyanok is, akik maguk vették kezükbe a sorsukat és vállalkozásba fogtak. A vállalkozóvá válás szintén új elemként jelent meg 1989 után és ugyancsak óriási kihívást jelentett. Hiszen új életritmust követelt, amit szintén nagyon nehéz megszokni, s ezt még a magasabb jövedelem, az anyagi biztonság tudata sem enyhíti. Az üzleti ügyek ,állandó” intézése, a 24 órás készenléti állapot, a reggeltől-estig való hajtás, a regenerálódásra fordítható idő hiánya vagy csekély volta, továbbá a tartós stressz mind együttesen olyan fizikai, idegi és szellemi megterhelést okoznak, amelyeket nagyon kevesen tudnak elviselni (Kiss 1995). Valószínüleg ezek is belejátszottak abba (pl. a tőkeszükösség és az alacsony iskolázottság mellett), hogy a vizsgált falvakban viszonylag kevesen vállalkoztak, sỏt az 1990-es évek eleji „vállalkozás alapítási láz” lecsillapodása után még csökkent is a számuk. 1998-ban Sarudon 31, Tiszakeszin 56, Tiszaszentimrén 47, Újszentmargitán 31 egyéni vállalkozót tartottak nyilván. A többségük a tercier szektorban tevékenykedett és jobbára egyszemélyes vállalkozás lévén a helyi foglalkoztatási gondok mérsékléséhez szinte alig járult hozzá. Éppen ezért még most is az egyik legsürgősebb feladat a munkahelyteremtés.

Végül is mindent figyelembe véve a válaszolóknak csak egy nagyon csekély hányada (Sarudon 7\%-a, Tiszakeszin 5\%-a, Tiszaszentimrén 3\%-a, Újszentmargitán 4\%-a) itélte meg úgy, hogy jobban él, mint 1989 elött, míg a többségük, Sarudon $73 \%$-uk, Tiszakeszin 75\%-uk, Tiszaszentimrén 60\%-uk és Újszentmargitán 80\%-uk állította ennek az ellenkezỏjét, vagyis hogy rosszabbul él a rendszerváltozás óta. Ezekböl az adatokból egyúttal arra is lehet következtetni egyrészt, hogy a falusi lakosság egy nagyon kicsi része gazdagodik, a nagyobb fele pedig szegényedik. A kevesebb, kedvezőbb helyzetbe kerülók köréhez főként a vállalkozók, a felsőfokú 
végzettségúek, a tulajdonnal rendelkezök sorolhatók, ugyanakkor a társadalom nagyobb hányadát kitevő rosszabb helyzetbe süllyedőkhöz a munkanélküliek, a nyugdíjasok, az alacsonyabb iskolázottságúak és a tulajdon nélküliek tartoznak. Valójában ezek a csoportok alkotják a rendszerváltozás „nyerteseit és veszteseit” ezekben a hátrányos helyzetú falvakban. Másrészt az is kitúnik ezekböl az adatokból, hogy már ma is igen erőteljes a lokális társadalom homogenizációja, amit a lefelé nivellálódás jellemez. Az elszegényedés folytatódása, amit a megkérdezettek zöme is jelzett, hosszú távon még súlyosabb társadalmi problémák, feszültségek forrása lehet, $\mathrm{s}$ mind több embert sodorhat a társadalom perifériájára.

\section{Összegzés}

A rendszerváltozás egy új fejlödési szakasz kezdetét hozta nemcsak az egyes falvak egésze, hanem az ottani háztartások és az egyének életében is. Természetesen a lokális politikai, gazdasági, társadalmi szervezetek, intézmények és az egyes háztartások, valamint az egyének eltéröen élték meg azt, s az új helyzetre különbözöképpen reagáltak. Így a túlélési stratégia mást jelent a települések egésze és mást a lokális szereplök szempontjából, mégis bizonyos hasonlóság is felfedhetỏ közöttük, habár az egyes csoportok stratégiái, reakciói térben és időben is változnak.

A közép-tiszavidékỉ tapasztalatok egyöntetủen arra utalnak, hogy a falusi lakosság életkörülményei, amelyek nagyon sok tényező bonyolult kölcsönhatásának a következményei, kedvezö és kedvezötlen változásokat egyaránt magukban hordoznak az elmúlt évtizedbeli nagyarányú társadalmi-gazdasági reformoknak tulajdonithatóan. Egyfelöl mérséklỏdött a tágabban értelmezett életkörülmények közti különbség a falvak és a városok között a tekintélyes infrastrukturális fejlesztéseknek köszönhetően. Másfelöl az egyes családok, egyének szükebb értelembe vett életkörülményeiben (pl. lakásfelszereltség, életmód) a különbségek fokozódása következett be. S az új évezred hajnalán ezeknek az éleződő társadalmi és térbeli különbségeknek a mérséklése jelöli ki a legfontosabb feladatokat. Elodázásuk beláthatatlan következményekkel járhat nemcsak a társadalom egészére, hanem falvaink sorsának XXI. század eleji alakulására nézve is.

\section{Irodalom}

Andorka R. (1996) Gazdasági, társadalmi változások és problémák a mai magyar falvakban. - A falu. 4.

7-17.0.

Bánlaky P. (1993) Algyö. Egy városrész-falu „intézménytérképe”, -A falu. 1. 27-42.0.

Beluszky P. (1999) Magyarország településfóldrajza I. Dialóg Campus Kiadó, Budapest.

Benedek L. (1994) Munkanélküliség a falusi közösségekben. - A falu. 2. 25-31.0.

Enyedi Gy. (1980) Falvaink sorsa. Magvetö Kiadó,Budapest.

Kiss É. (1989) A Közép-Tiszavidék megyehatár menti településeinek gazdasági fejb̆dése és kőzigazgatási területbeosztása. - Alfoldi Tanulmányok. XIII. kötet. 169-185.o. 
Kiss É. (1992) A szellemi potenciál jellemzöje a Közép-Tiszavidéken. - Alföldi Tanulmányok. XIV. kötet. 139-157,o.

Kiss É. (1995) Az egyéni vállalkozások Pest megyében (I), - Statisztikai Szemle. 10. 832-838.o.

Kovács T (1991) A határmenti fekvés szerepe a falusi telepuilések életében. - Tér és Társadalom. 1. 41-53.0.

Mészáros R. (1988) A helyi hatalom minösége és a település. Településfejlesztés, helyi társadalom, önkormányzat, - Csefkó F.-Szirtes G. (szerk.), MTA RKK, Pécs. 70-73.o.

Oksa, J.(1997) Uncertain future of Karelian Forestry village. Manuscript.

Rey, V.-Bachvarov, M. (1998) Rural settlements in transition-agricultural and countryside crisis in Central-Eastern Europe. - GeoJournal. 4. 345-353.0.

Tamasi M. (1993) A falusi civilizálódás és polgárosodás. - Gazdálkodás. 5. 38-50.o.

Tykkylainen, M. (1997) Theoretical and methodological underpinnings of the study on rural survival strategiesin transitional countries. Manuscript.

Varis, E. (1997) Comparing the post-socialist countryside in Hungary and in Russian Karelia- some methodological aspects. Manuscript.

Weixlbaumer, N. (1993) Suggestions regarding the measurement of the quality of life of the population in rural areas in Austria. A contribution to agricultural geography. - Geographical Studies-Nitra. 2. 85-96.o. 